\title{
A FIRST FINDING AND A NEW SPECIES OF WOLF-SNAKE (LYCODON MACKINNONI WALL, 1906) OF THE OPHIDIAN FAUNA OF AZAD KASHMIR (PAKISTAN)
}

\author{
Abu ul H. Faiz ${ }_{1,2}$, Fakhar-I-Abbas ${ }^{2}$, Mikhail F. Bagaturov ${ }^{3,4,5}$, \\ Lariab Zahra ${ }^{1,6}$, Mehboob ul Hassan ${ }^{6}$ and Tanveer Akahter ${ }^{6}$ \\ ${ }^{1}$ Bio Resource Research Centre \\ 34-Bazar Road, G-6/4, Islamabad, Pakistan \\ E-mail:sabulhussan@gmail.com \\ ${ }^{2}$ Women University of Azad Jammu and Kashmir \\ Bagh Campus, Pakistan \\ E-mail:info@wuajk.edu.pk \\ ${ }^{3}$ Zoological Institute of the Russian Academy of Sciences \\ 1 Universitetskaya emb., Saint Petersburg Petersburg 199034, Russia \\ ${ }^{4}$ Athens Institute for Education and Research \\ 8 Valaoritou, Athena 106 71, Greece \\ ${ }^{5}$ International Union of Conservation of Nature: The Species Survival Commission: CPSG\&ASG Groups \\ 28 Rue Mauverney, Gland 1196, Switzerland \\ E-mail:bbigmojo@mail.ru \\ ${ }^{6}$ University of Punjab \\ Canal Bank Rd, Punjab University New Campus, Lahore, Punjab, Pakistan
}

Received 6 March 2018, revised 24 May 2018, accepted 14 June 2018

\begin{abstract}
The present study was conducted to research the herpetofaunal in the Bagh area (the central part of State of Azad Jammu and Kashmir, Azad Kashmir, Pakistan). It lasted from May 2015 till November 2016. As a result, 5 specimens of the Western-Himalayan endemic wolf-snake species Lycodon mackinnoni were recorded by visual encounter. These findings were new for the habitat of the species and for the specific composition of the ophidian fauna of both the Azad Kashmir area and Pakistan in the whole.

Key words: Lycodon mackinnoni, Western-Himalayan endemic species, new record, conservation, Azad Kashmir, Bagh area, Himalayas, Pakistan, anthropogenic pressure.
\end{abstract}

DOI: https://doi.org/10.18500/1814-6090-2018-16-3-4-153-158

\section{INTRODUCTION}

The biodiversity found in the Himalayas is accounted by historical events that occurred during the Eocene, by geological changes and created ecosystem heterogeneity for wider distribution of species (Khan, 1991). The diversity and distribution of snakes in Himalayas is also due to these historical factors are directly related to the diversity and distribution of species, and the same occurs with snakes (Khan, 1980). In the Himalayas, established reptilian groups have diversified in response to harsh prevailing conditions, such as hostile winter and humid summer open formations (Khan, 1996).

The ophidian fauna of eastern and middle Himalayas is studied by various zoologists such as (Boulenger, 1890; Smith, 1935, 1943) and western Himalayas by Minton (1966) and Mertens (1969). The ophidian fauna of Kashmir in western Himalayas is worked out by Murphy et al (1979) and Khan (1990) but Pir Panjal range was least studied. The present study was designed to explore the area to find the diversity and distribution of serpentine fauna.

\section{MATERIAL AND METHODS}

Study area. The State of Azad Jammu and Kashmir (AJK 33-36 N, 73-75 E) has an area of some $13200 \mathrm{~km}^{2}$, falling in the western extremities of the Himalayan range with altitudes gradually rising from around $500 \mathrm{~m}$ above sea level in southern latitudes to $6500 \mathrm{~m}$ a.s.1. The northern part of State have cold mountainous with Jamgarh Peak 15,531 feet (4,734 meters). The present study was conducted in central part of Kashmir (Bagh) which is generally mountainous but weather remains moderate hot in summers and cold, chilly in winter (see Table 1 for temperature data and Fig. 1 for map of study area).

Methods. We surveyed 24 line transects randomly $($ diameter $=33.33 \mathrm{~m})$ in such a way to present whole sampling of district Bagh. The position of line transect was marked with GPS (Garmin Foretrex 
Abu ul H. Faiz, Fakhar-I-Abbas, Mikhail F. Bagaturov et al.

Table 1. Temperature data of the study area*

\begin{tabular}{l|c|c}
\hline \multicolumn{1}{c|}{ Month } & Low temp & High temp \\
\hline February & $7.62 \pm 0.4$ & $22.7 \pm 0.7$ \\
\hline March & $13.29 \pm 0.3$ & $24.09 \pm 0.8$ \\
\hline April & $16.83 \pm 0.4$ & $31.43 \pm 0.7$ \\
\hline May & $23.51 \pm 0.3$ & $38.09 \pm 0.6$ \\
\hline June & $26.53 \pm 0.3$ & $39.66 \pm 0.3$ \\
\hline July & $25.12 \pm 0.3$ & $34.87 \pm 0.5$ \\
\hline August & $24.35 \pm 0.3$ & $34.64 \pm 0.5$ \\
\hline September & $24.43 \pm 0.2$ & $35.26 \pm 0.2$
\end{tabular}

Note. * Available at: http://www.accuweather.com (accessed December, 2017).

401). The location of transects with GPS reading is given at the Table 2 . The study was conducted from 1 February 2015 to 12 September 2016. We detected snakes in each transects using active, mostly nocturnal searches following a visual encounter survey (VES) with five people (Heyer et al., 1994). The total time taken in each transect was circa forty-eight hours.

Searches consisted of walking slowly through each quadrant, thoroughly examining suitable patches of habitat, gently raking through leaf litter, and turning over logs, boulders and rock cervices. When we observed snake, we identified the species to the lowest possible taxon, tabulated the number of individuals and recorded the altitude and habitat area. We photographed animals as they were encountered. When we were unable to identify a specimen, we captured, humanely euthanized it and preserved it in a 70\% solution of alcohol for later identification (Smith, 1943).

All specimens were captured and identified on available morphological data (Wall, 1906; Lanza, 1999). All external morphological data provide into Table 3 and Table 4 below.

The voucher specimens were collected from human habitation area except one sample which was

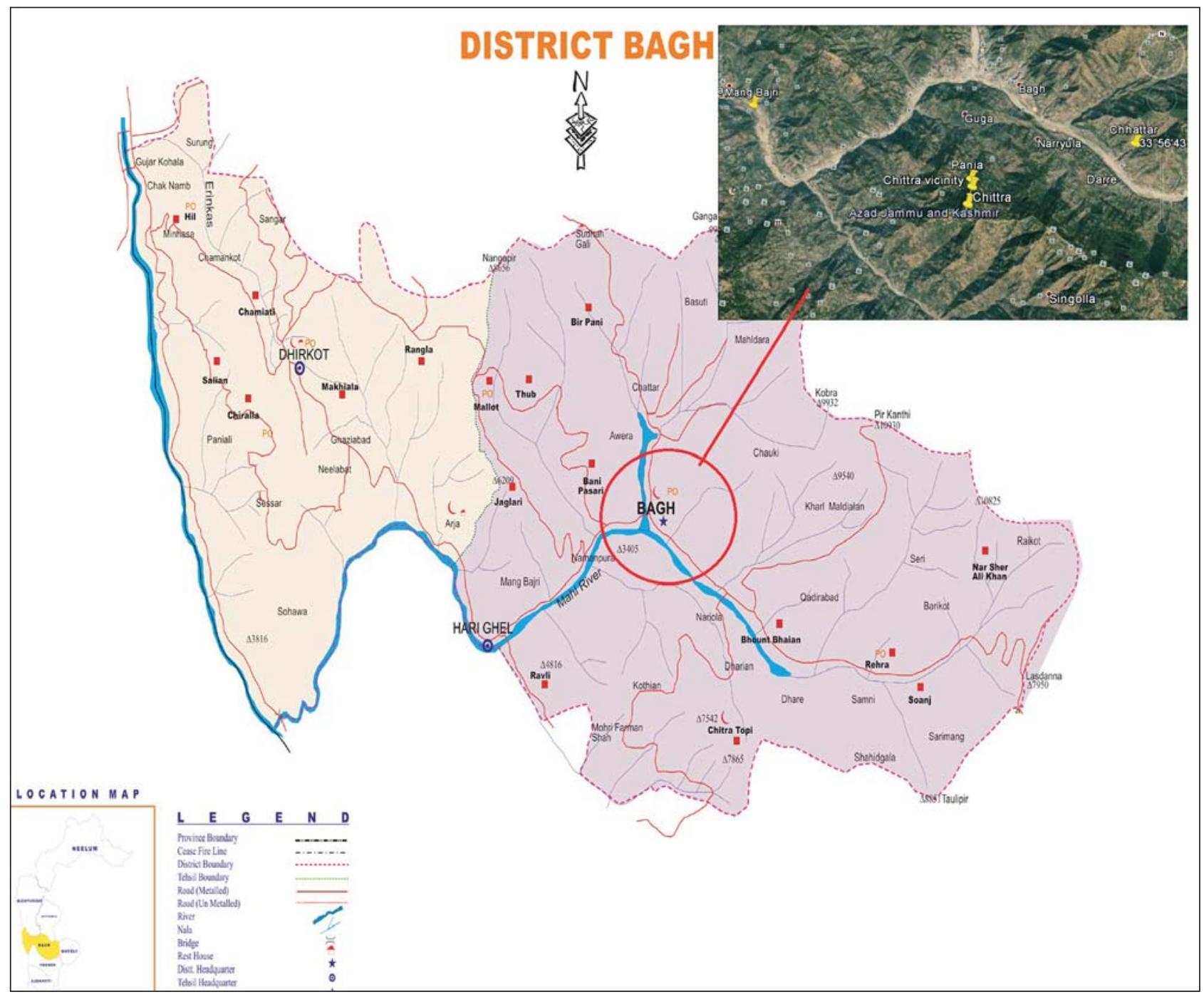

Fig. 1. Map of study area. Localities of found of MacKinnon's wolf snake (Lycodon mackinnoni Wall, 1906) marked in yellow 
Table 2. GPS coordinate of sampled study area with related samples (in bold)

\begin{tabular}{|c|c|c|c|c|c|}
\hline No. & Localities & Latitude & Longitude & $\begin{array}{c}\text { Elevation } \\
\text { (in meters) }\end{array}$ & $\begin{array}{c}\text { Presence/ } \\
\text { absence }\end{array}$ \\
\hline 1 & Chittra & $33^{\circ} 55^{\prime} 24.3^{\prime \prime} \mathrm{N}$ & $73^{\circ} 46^{\prime} 0.75^{\prime \prime} \mathrm{E}$ & 1965.65 & female \\
\hline 2 & Nari & $33^{\circ} 55^{\prime} 52.0^{\prime \prime} \mathrm{N}$ & $73^{\circ} 46^{\prime} 7.55^{\prime \prime} \mathrm{E}$ & 1918.71 & $x$ \\
\hline 3 & Sanna & $33^{\circ} 55^{\prime} 55.7^{\prime \prime} \mathrm{N}$ & $73^{\circ} 46^{\prime} 7.88^{\prime \prime} \mathrm{E}$ & 1908.96 & $x$ \\
\hline 4 & Chola & $33^{\circ} 55^{\prime} 57.8^{\prime \prime} \mathrm{N}$ & $73^{\circ} 46^{\prime} 7.92^{\prime \prime} \mathrm{E}$ & 1912.31 & $x$ \\
\hline 5 & Pania & $33^{\circ} 55^{\prime} 58.4^{\prime \prime} \mathrm{N}$ & 734ㅇ'6.07"E & 1911.09 & female \\
\hline 6 & Gehla & $33^{\circ} 55^{\prime} 18.0^{\prime \prime} \mathrm{N}$ & $73^{\circ} 46^{\prime} 1.90^{\prime \prime E}$ & 1969.00 & $x$ \\
\hline 7 & Dharan & $33^{\circ} 55^{\prime} 13.6^{\prime \prime} \mathrm{N}$ & $73^{\circ} 46^{\prime} 2.12^{\prime \prime} \mathrm{E}$ & 1977.23 & $x$ \\
\hline 8 & Parota & $33^{\circ} 55^{\prime} 12.0^{\prime \prime} \mathrm{N}$ & $73^{\circ} 46^{\prime} 1.90^{\prime \prime} \mathrm{E}$ & 1964.74 & $x$ \\
\hline 9 & Kals & $33^{\circ} 55^{\prime} 24.3^{\prime \prime} \mathrm{N}$ & $73^{\circ} 46^{\prime} 0.80^{\prime \prime} \mathrm{E}$ & 1977.84 & $x$ \\
\hline 10 & Numanpura & $33^{\circ} 58^{\prime} 36.8^{\prime \prime} \mathrm{N}$ & $73^{\circ} 44^{\prime} 6.35^{\prime \prime} \mathrm{E}$ & 989.38 & $x$ \\
\hline 11 & Banipasari & $33^{\circ} 58^{\prime} 38.3^{\prime \prime} \mathrm{N}$ & $73^{\circ} 44^{\prime} 3.68^{\prime \prime E}$ & 1079.60 & $x$ \\
\hline 12 & Gehla & $33^{\circ} 58^{\prime} 23.6^{\prime \prime} \mathrm{N}$ & $73^{\circ} 44^{\prime} 6.09^{\prime \prime} \mathrm{E}$ & 984.50 & $x$ \\
\hline 13 & Kaffalgar & $33^{\circ} 57^{\prime} 04.3^{\prime \prime} \mathrm{N}$ & $73^{\circ} 42^{\prime} 8.32^{\prime \prime} \mathrm{E}$ & 1027.17 & $x$ \\
\hline 14 & Mang bajri & $33^{\circ} 57^{\prime} 49.4^{\prime \prime} \mathrm{N}$ & $73^{\circ} 40^{\prime} 6.25^{\prime \prime} \mathrm{E}$ & 841.24 & female \\
\hline 15 & Dolman & $33^{\circ} 58^{\prime} 09.0^{\prime \prime} \mathrm{N}$ & $73^{\circ} 40^{\prime} 1.28^{\prime \prime} \mathrm{E}$ & 821.43 & $x$ \\
\hline 16 & Apper parian & $33^{\circ} 58^{\prime} 12.3^{\prime \prime} \mathrm{N}$ & $73^{\circ} 40^{\prime} 1.58^{\prime \prime} \mathrm{E}$ & 844.29 & $x$ \\
\hline 17 & Arja & $33^{\circ} 58^{\prime} 40.7^{\prime \prime} \mathrm{N}$ & $73^{\circ} 39^{\prime} 5.58^{\prime \prime} \mathrm{E}$ & 814.12 & $x$ \\
\hline 18 & Jehala & $33^{\circ} 58^{\prime} 59.2^{\prime \prime} \mathrm{N}$ & $73^{\circ} 39^{\prime} 3.21^{\prime \prime E}$ & 851.91 & $x$ \\
\hline 19 & Saman & $33^{\circ} 58^{\prime} 32.1^{\prime \prime} \mathrm{N}$ & $73^{\circ} 39^{\prime} 4.25^{\prime \prime} \mathrm{E}$ & 776.02 & $x$ \\
\hline 20 & Chittra vicinity & $33^{\circ} 55^{\prime} 47.17^{\prime \prime} \mathrm{N}$ & $73^{\circ} 46^{\prime} 7.62^{\prime \prime} \mathrm{E}$ & 1118.92 & male \\
\hline 21 & Dairaan & $33^{\circ} 55^{\prime} 57.02^{\prime \prime} \mathrm{N}$ & $73^{\circ} 45^{\prime} 6.60^{\prime \prime} \mathrm{E}$ & 758.34 & $x$ \\
\hline 22 & Narryula & $33^{\circ} 56^{\prime} 54.42^{\prime \prime} \mathrm{N}$ & $73^{\circ} 47^{\prime} 55.01^{\prime \prime E}$ & 793.39 & $x$ \\
\hline 23 & Hullarh & $33^{\circ} 58^{\prime} 7.57^{\prime \prime} \mathrm{N}$ & $73^{\circ} 47^{\prime} 6.17^{\prime \prime E}$ & 790.34 & $x$ \\
\hline 24 & Chhattar & $33^{\circ} 56^{\prime} 43.54^{\prime \prime} \mathrm{N}$ & $73^{\circ} 50^{\prime} 18.64^{\prime \prime} \mathrm{E}$ & 783.94 & male \\
\hline
\end{tabular}

Table 3. Morphometric data of captured specimens of Lycodon mackinnoni Wall from District Bagh (AJK), Pakistan (all measurements in $\mathrm{mm}$ )

\begin{tabular}{c|c|c|c|c|c|c|c}
\hline No. & $\begin{array}{c}\text { Head } \\
\text { length }\end{array}$ & $\begin{array}{c}\text { Eye } \\
\text { diameter }\end{array}$ & $\begin{array}{c}\text { Distance } \\
\text { b/w eyes }\end{array}$ & $\begin{array}{c}\text { Tail } \\
\text { length }\end{array}$ & $\begin{array}{c}\text { Head } \\
\text { width }\end{array}$ & $\begin{array}{c}\text { Total } \\
\text { body } \\
\text { length }\end{array}$ & $\begin{array}{c}\text { Snout } \\
\text { vent } \\
\text { length }\end{array}$ \\
\hline 1 & 11 & 0.9 & 3.8 & 79 & 5.1 & 436 & 353 \\
\hline 2 & 10 & 0.8 & 3.6 & 78 & 5.0 & 430 & 352 \\
\hline 3 & 9 & 0.85 & 3.7 & 77 & 4.9 & 425 & 350 \\
\hline 4 & 15.4 & 0.5 & 4.05 & 68.58 & 5.4 & 330.2 & 265 \\
\hline 5 & 14 & 0.3 & 4.2 & 70 & 5.7 & 350.3 & 260
\end{tabular}
specimens). captured on stones of stream (Nala Mahl) on stony area.

\section{RESULTS}

During the survey we have recorded MacKinnon's wolf snake (Lycodon mackinnoni Wall, 1906) from five different locations: Chittra, Pania, Mang bajri, Chittra vicinity, Chhattar, in rural areas of district Bagh Azad Kashmir, Pakistan. The sample No. 1 was collected from location Chittra, transect No.1 (one female, Fig. 2) while second female specimen (sample No. 2) was collected from location Pania (Fig. 3), with transect No. 5. The third female (sample No. 3, Fig. 6) was collected from location Mang bajri, with transect No. 14. The first male (sample No. 4, Fig. 4) was collected from location of Chittra vicinity with transect No. 20, while second male (sample No. 5, Fig. 5) was collected from location Chhattar with transect No. 24 (see Table 2 for elevation data of all captured

\section{DISCUSSION}

The found species (L. mackinnoni) is not present before in the report of ophidian fauna of western Himalayas in Azad Jammu and Kashmir (Khan, 1996) as well as in the check list of ophidian fauna of Pakistan where Genus Lycodon is represented by three species: L. aulicus (Linnaeus, 1758) by its nominotypical subspecies, L. striatus bicolor (Nikolsky, 1903) and L. travancoricus (Beddome, 1870) (Khan, 2003).

These findings extend Table 4. Pholidosic count of Lycodon mackinnoni Wall from District Bagh (AJK), Pakistan

\begin{tabular}{l|c|c|c|c|c}
\hline \multicolumn{1}{c|}{ Scalation } & \multicolumn{5}{c}{ Number } \\
\hline Supra labial & 8 & 8 & 8 & 8 & 8 \\
\hline Infralabial & 7 & 7 & 7 & 7 & 7 \\
\hline Supraocular & 2 & 2 & 2 & 2 & 2 \\
\hline Parietal & 2 & 2 & 2 & 2 & 2 \\
\hline Prefrontal & 2 & 2 & 2 & 2 & 1 \\
\hline Preocular & 1 & 1 & 1 & 1 & 1 \\
\hline Post ocular & 1 & 1 & 1 & 1 & 1 \\
\hline Loreal & 1 & 1 & 1 & 1 & 2 \\
\hline Intranasal & 2 & 2 & 2 & 2 & $5(2+3)$ \\
\hline Temporal & $5(2+3)$ & $5(2+3)$ & $5(2+3)$ & $5(2+3)$ & $17-15$ \\
\hline Dorsal body scale & $17-15$ & $17-15$ & $17-15$ & $17-15$ & $193(163-187)$ \\
\hline Ventrals & $193(163-187)$ & $193(163-187)$ & $193(163-187)$ & $193(163-187)$ & 53 pairs
\end{tabular}
the distributional range of the species, which was recently recorded from neighboring area of India (Manhas et al., 2015), and is a newly recorded range of L. mackinnoni at Tolipir hills of Pir punjal in Himalayas while this species was also reported at Mussoorie hills of Himalayas (Wall, 1906). The distribution range in western Himalayas at three locations (Mussoorie, Alomar and Muktesar) was also recorded before by Smith (1943). 


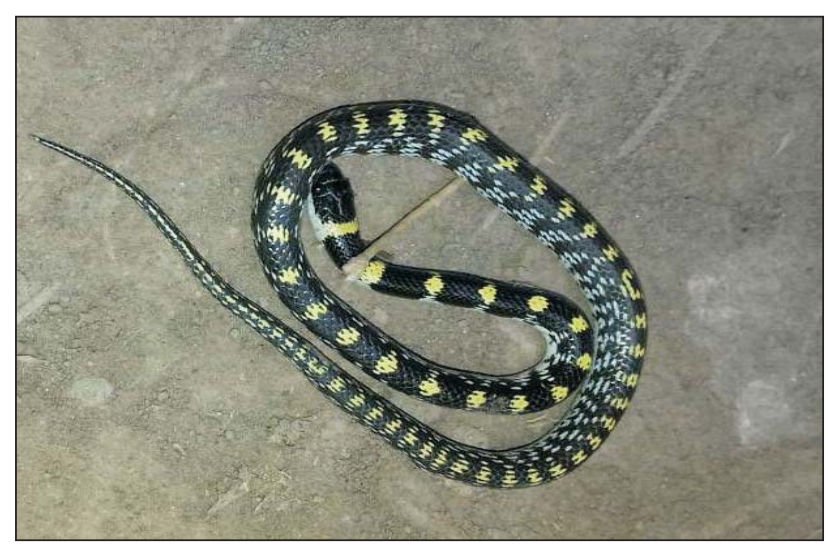

Fig. 2. MacKinnon's wolf snake (Lycodon mackinnoni Wall, 1906). Specimen no. 1

The present collection describe elevation range of the distribution of L. mackinnoni at elevation range as follows: Chittra - 1965.65 m a.s.1., Pania - 1911.09 $\mathrm{m}$ a.s.1., Mang Bajri - $841.24 \mathrm{~m}$ a.s.1., Chitra vicinity $1118.92 \mathrm{~m}$ a.s.l. and Chhattar $-783.94 \mathrm{~m}$ a.s.1., while formerly it was reported at maximum elevation range of $1860 \mathrm{~m}$ a.s.l. (Wall, 1906).

The specimens was collected at habitats of human vicinity in maize crop fields except one specimen (Fig. 6) which was found at the stream edge on trenched stone. The maize crop fields are in the territory of human habitat and tally the habitat description of L. mackinnoni (Wall, 1906) and also confirm the observations of habitat analysis by Manhas et al. (2015).

The morphometric measurements of total body length $(0.43,0.42,0.42 \mathrm{~m})$ of three samples are approximately same as reported previously (Wall, 1906; Manhas et al., 2015), while the remaining two samples

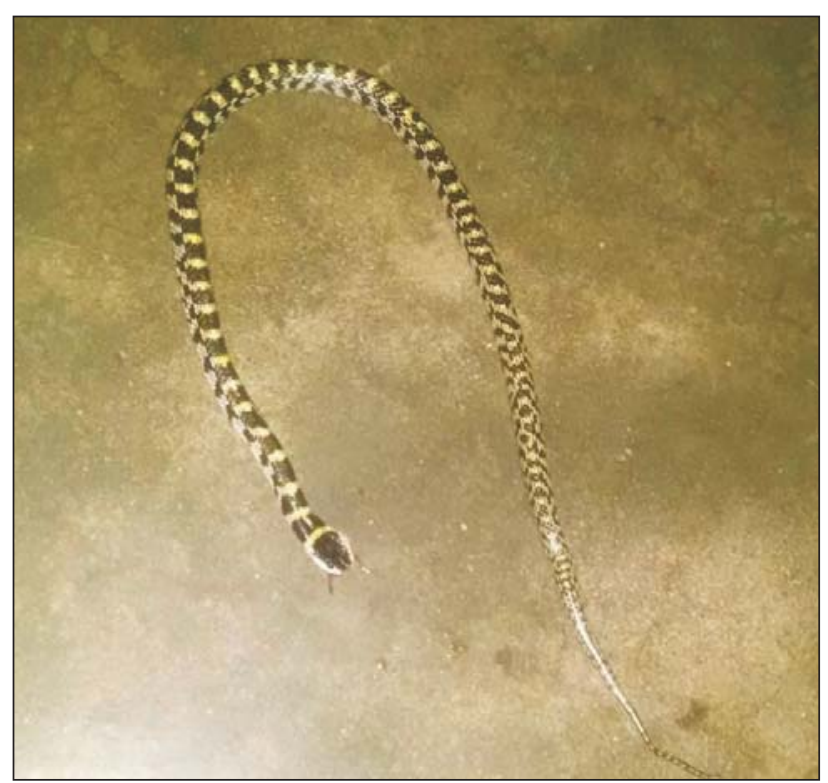

Fig. 3. MacKinnon's wolf snake (Lycodon mackinnoni Wall, 1906). Specimen no. 2 have measurements $0.26 \mathrm{~m}$ and $0.25 \mathrm{~m}$ accordingly. The snout length of first three samples is nearly same (35.3, 35.2 and $35.0 \mathrm{~cm}$ respectively) as reported

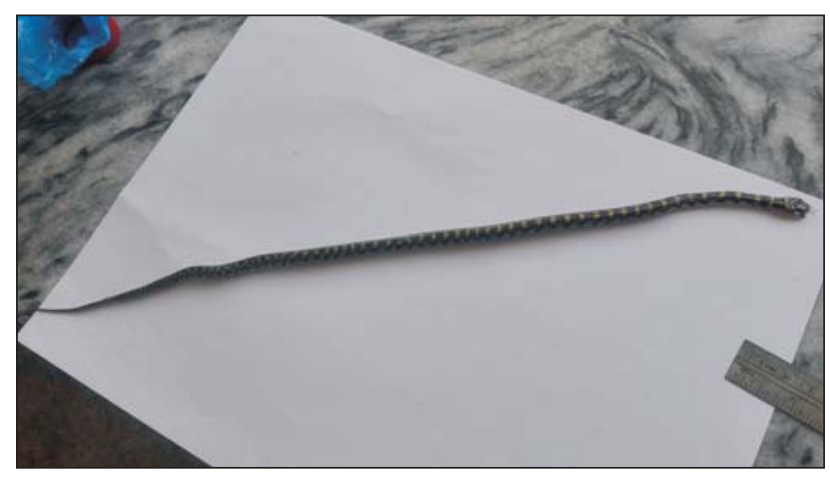

Fig. 4. MacKinnon's wolf snake (Lycodon mackinnoni Wall, 1906). Specimen no. 3

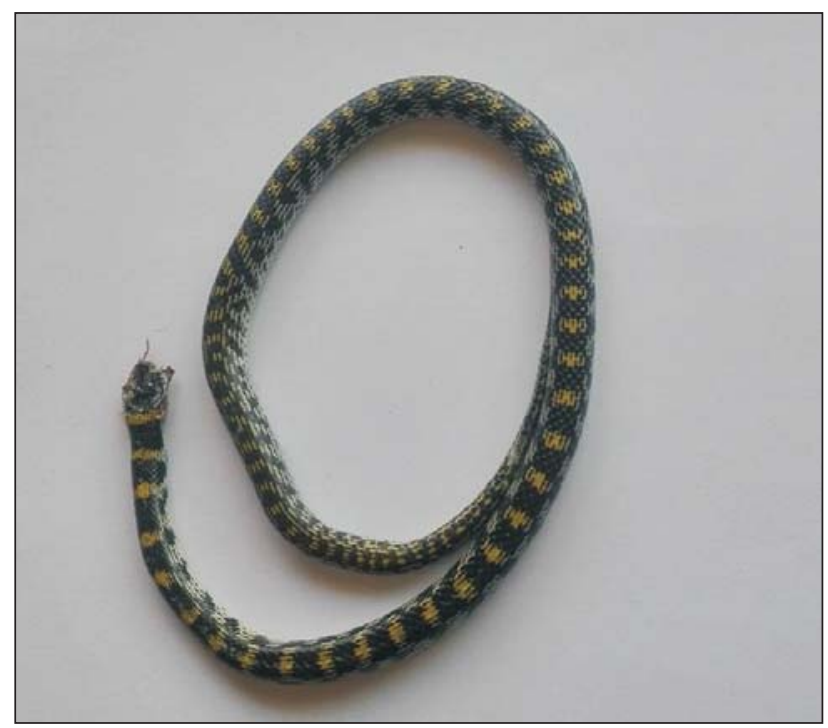

Fig. 5. MacKinnon's wolf snake (Lycodon mackinnoni Wall, 1906). Specimen no. 4

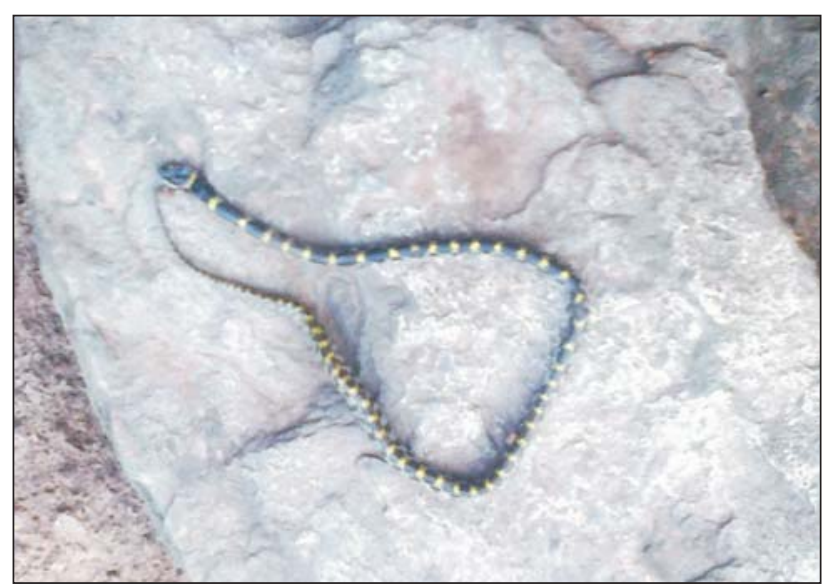

Fig. 6. MacKinnon's wolf snake (Lycodon mackinnoni Wall, 1906). Specimen no. 5 


\section{A FIRST FINDING AND A NEW SPECIES OF WOLF-SNAKE}

(Wall, 1906; Manhas et al., 2015) while last two samples measured 26.5 and $26.0 \mathrm{~cm}$. The tail length, head width and eye diameter, distance between eyes are approximately same as reported by F. Wall (1906) and A. Manhas et al. (2015).

The Mackinnon's Wolf snake (Lycodon mackinnoni) sampled in the study area is also facing anthropogenic pressure and is killed by human being due to fear of biting and needs immediate awareness for conservation of this beautiful harmless Western Himalayan endemic species. The anthropogenic pressure on habitat, vegetation analysis of landscape is given by a number of studies (Faiz et al., 2014, 2015).

\section{REFERENCES}

Boulenger G. A. Fauna of British India, including Ceylon and Burma. Reptilia and Batrachia. London, Taylor and Francis, 1890. $541 \mathrm{p}$.

Heyer W. R., Donnelly M. A., Mcdiarmid R. W., Hayek L. C., Foster M. S. Measuring and monitoring biological diversity: Standard methods for amphibians. Washington and DC, Smithsonian Institution Press, 1994. 364 p.

Faiz H. A., Mohammad A. G., Mian A., Akhtar T. Floral Diversity of Tolipir National Park (TNP), Azad Jammu and Kashmir, Pakistan. Biologia (Pakistan), 2014, vol. 60 , no. 1 , pp. 43-55.

Faiz H. A., Fakhar-i-Abbas, Zahra L. Anthropogenic influences on the tolipir landscape, lesser Himalayas, Pakistan. J. of Bioresource Manage, 2015, vol. 2, no. 4, pp. 20-27.

Khan A. Q., Khan M. S. Snakes of State of Azad Jammu and Kashmir. Proceedings of Pakistan Congress of Zoology, 1996, no. 16, pp. 173-182.

Khan M. S. Affinities and Zoogeography of herpetiles of Pakistan. Biologia, 1980, no. 26, pp. 113-171.
Khan M. S. Venomous terrestrial snake of Pakistan and snake bite problem. In: Snake of medical importance (Asia pacific regions). Singapore, National University of Singapore, 1990, pp. 419-446.

Khan M. S. Morphological specialization of the buccopharyngeal region of the anuran larvae and its bearing mode of larval feeding. $\mathrm{PhD}$ thesis, University of Punjab Lahore (Pakistan), 1991.

Khan M. S. Key and checklist to the snakes of Pakistan with special reference to the venomous snakes. Pakistan J. Zoology. Suppl. Ser., 2003, no. 1, pp. 1-53.

Lanza B. A new species of Lycodon from the Philippines, with a key to the genus (Reptilia Serpentes Colubridae). Tropical Zoology, 1999, vol. 12, no. 1, pp. 89-104.

Manhas A., Wanganeo R. N., Wanganeo A. First record of Himalayan Wolf Snake (Lycodon mackinnoni Wall, 1906) in Doda District of Lower Himalayas, Jammu and Kashmir, India. World Research J. of Biological Sciences, 2015, vol. 1, no. 1, pp. 2-4.

Mertens R. Die Amphibien und Reptilien WestPakistans. Stuttgarter Beiträge zur Naturkunde, 1969, Bd. 197, S. 1-96.

Minton S. A. A contribution to the herpetology of West Pakistan. Bulletin of the American Museum of Natural History, 1966, vol. 134, no. 2, pp. 31-184.

Murthy T. S. N., Sharma B. D., Sharma T. Second report on the herpetofauna of Jammu and Kashrnir. The Snake, 1979, no. 11, pp. 234-241.

Smith M. A. Reptilia and amphibia. Vol. II. Sauria. The fauna of British India Ceylon and Burma. London, Taylor and Francis, 1935. 440 p.

Smith M. A. Reptilia and amphibia. Vol. III. Serpentes The fauna of British India Ceylon and Burma. London, Taylor and Francis, 1943. 583 p.

Wall F. A new Himalayan snake (Lycodon mackinnoni). J. of the Bombay Natural History Society, 1906, vol. 17, pp. 29-30.

\section{Cite this article as:}

Faiz A. ul H., Abbas-I-Fakhar, Bagaturov M. F., Zahra L., Hassan ul M., Akahter T. A First Finding and a New Species of Wolf-Snake (Lycodon mackinnoni Wall, 1906) of the Ophidian Fauna of Azad Kashmir (Pakistan). Current Studies in Herpetology, 2018, vol. 18, iss. 3-4, pp. 153-158 (in Russian). DOI: https://doi.org/10.18500/1814-6090-2018-18-3-4-153-158 


\title{
ПЕРВАЯ НАХОДКА И НОВЫЙ ВИД ВОЛКОЗУБА (LYCODON MACKINNONI WALL, 1906) ОФИДИОФАУНЫ АЗАД КАШМИРА (ПАКИСТАН)
}

\author{
А. ул Х. Файз ${ }^{1,2}$, Фахар-И-Аббас ${ }^{2}$, М. Ф. Багатуров ${ }^{3,4,5}$, \\ Л. Захра ${ }^{1,6}$, М. ул Хассан ${ }^{6}$, Т. Акатер ${ }^{6}$ \\ ${ }^{1}$ Исследовательский иентр биоразнообразия \\ Пакистан, Ж-6/4, Исламабад, 34-Базар роад \\ E-mail:sabulhussan@gmail.com \\ ${ }^{2}$ Женский университет Азад Джамму и Кашмира \\ Пакистан, Багх Кампус \\ E-mail: info@wuajk.edu.pk \\ 3 Зоологический институт Российской академии наук \\ Россия, 199034, Санкт-Петербург, Университетская набережная, 1 \\ ${ }^{4}$ Афинский институт образования и исследований \\ Греция, 106 71, Афины, Валаориту, 8 \\ ${ }_{5}^{5}$ Международный союз охраны природы: Комиссия по выживанию видов. \\ Швейцария, 1196, Гланд, Рю Маверни, 28 \\ E-mail:bbigmojo@mail.ru \\ ${ }^{6}$ Государственный университет Пенджаба \\ Пакистан, Пенджаб, Лахоре, Канал Банк Роад, Нью Кампус
}

Поступила в редакцию 20.02.2018, после доработки 11.04.2018, принята 26.05.2018

\begin{abstract}
Настоящее исследование проводилось с целью изучения герпетофауны области Багх (центральная часть Штата Азад Джамму и Кашмир, Азад Кашмир, Пакистан). Оно проходило в период с мая 2015 г. по ноябрь 2016 г. В результате были найдены 5 экземпляров западно-гималайского эндемичного вида Lycodon mackinnoni методом визуального обнаружения. Эти находки явились новыми для ареала распространения вида, а также для видового состава офидиофауны, как Азад Кашмира, так и Пакистана в целом.

Ключевые слова: Lycodon mackinnoni, западно-гималайский эндемичный вид, новые данные, сохранение вида, Азад Кашмир, Багх, Гималаи, Пакистан, антропогенный прессинг.
\end{abstract}

DOI: https://doi.org/10.18500/1814-6090-2018-18-3-4-153-158

\section{Образец для цитирования:}

Faiz A. ul H., Abbas-I-Fakhar, Bagaturov M. F., Zahra L., Hassan ul M., Akahter T. 2018. A First Finding and a New Species of Wolf-Snake (Lycodon mackinnoni Wall, 1906) of the Ophidian Fauna of Azad Kashmir (Pakistan) [Фaüз A. ул Х., Аббас-И-Фахар, Багатуров М. Ф., Захра Л., Хассан ул М., Акатер Т. 2018. Первая находка и новый вид волкозуба (Lycodon mackinnoni Wall, 1906) офидиофауны Азад Кашмира (Пакистан)] // Современная герпетология. T. 18, вып. 3/4. C. 153 - 158. DOI: https://doi.org/10.18500/1814-6090-2018-18-3-4-153-158 